\title{
Effect of gamma radiation on microbiological changes in dry salted ribbon fish (Lepturacanthus savala, Cuvier, 1829)
}

\author{
M.K. BHALALA And S.M. ZOFAIR*
}

Department of Harvest and Post-Harvest Technology, College of Fisheries (J.A.U.), VERAVAL (GUJARAT) INDIA

Email: prof_zofair@yahoo.co.in

*Author for Correspondence

Research chronicle : Received : 19.03.2015; Revised : 07.05.2015; Accepted : 21.05.2015

\section{SUMMARY :}

A study was conducted to determine the effects of gamma radiation on microbiological qualities of dry salted ribbon fish (Lepturacanthus savala) collected from fish drying yard. Results of microbiological analysis showed that total plate count in non-irradiated ribbon fish was $6.9 \pm 0.15 \mathrm{log}$ cfug $^{-1}$ which was significantly reduced by $1 \operatorname{logs}$ at $1.0 \mathrm{kGy}, 2$ to $3 \operatorname{logs}$ at $3.0 \mathrm{kGy}$ and 3 to $4 \operatorname{logs}$ at $5.0 \mathrm{kGy}$ gamma radiation. Maximum staphylococci count was noted in non-irradiated ribbon fish $\left(3.17 \pm 0.17 \log _{\mathrm{cfug}^{-1}}\right)$ compared to irradiated with $1.0 \mathrm{kGy}\left(2.63 \pm 0.50 \mathrm{log} \mathrm{cfug}^{-1}\right), 3.0 \mathrm{kGy}(2.35 \pm 0.35$ $\left.\log \mathrm{cfug}^{-1}\right)$ and $5.0 \mathrm{kGy}\left(1.95 \pm 0.50 \log _{\mathrm{cfug}}{ }^{-1}\right)$ on $0^{\text {th }}$ day. At the end of experiment, the halophilic count was $4.98 \pm 0.40 \operatorname{log~cfug~}^{-1}$ in control while in $5.0 \mathrm{kGy}$ irradiated fish sample it was $1.49 \pm 0.49 \mathrm{log} \mathrm{cfug}^{-1}$. Vibrio cholera, Salmonella and Shigella and E.coli were not detected in experimental fish samples during investigation. Total fungal count recorded was $2.48 \pm 0.03 \mathrm{log} \mathrm{cfug}^{-1}$ in non-irradiated ribbon fish but it was totally eliminated in $5.0 \mathrm{kGy}$ irradiated fish samples. Gamma irradiation doses (1.0, 3.0 and $5.0 \mathrm{kGy})$ had no significant effect $(P>0.05)$ on sensory properties (appearance, colour, odour and texture) of dry salted ribbon fish sample neither at zero time nor during nine month storage periods. It can be concluded that, gamma irradiation dose of 3.0 and $5.0 \mathrm{kGy}$ had a significant $(P<0.05)$ effects on decreasing microbial load and improve the microbiological safety of dry salted ribbon fish without any adverse effects on their sensory quality.

KEY WORDS : Dry fish, Gamma irradiation, Microbiological, Sensory attributes, Ribbon fish

How to cite this paper : Bhalala, M.K. and Zofair, S.M. (2015). Effect of gamma radiation on microbiological changes in dry salted ribbon fish (Lepturacanthus savala, Cuvier, 1829). Internat. J. Proc. \& Post Harvest Technol., 6 (1) : 93-100. 